\title{
Pengaruh Persepsi Anggota pada Sharia Compliance, Komitmen Agama dan Atribut Produk Islam Terhadap Customer's Trust yang Berdampak pada Keputusan Menggunakan Jasa Lembaga Keuangan Syariah (Studi Pada Bmt Amanah Ummah Sukoharjo)
}

\section{Iin Emy Prastiwi}

Program Studi Ekonomi Syariah, Sekolah Tinggi Ilmu Ekonomi AAS Surakarta, Indonesia *Email korenpondensi: iinemyprastiwi @ gmail.com

Recieved 06-03-2018 | Revised 21-03-2018 | Accepted 24-03-2018

Pemahaman dan pengetahuan masyarakat tentang lembaga keuangan syariah akan mempengaruhi pandangannya terhadap lembaga keuangan syariah tersebut yang berdampak pada keputusan masyarakat dalam menggunakan jasa lembaga keuangan syariah. Tujuan dalam penelitian ini adalah untuk membuktikan secara empiris faktor-faktor apa saja yang mempengaruhi keputusan masyarakat dalam menggunakan jasa lembaga keuangan syariah. Penelitian ini merupakan penelitian survei dengan mengambil lokasi pada BMT Amanah Ummah di Sukoharjo. Peneitian ini mengambil sampel sebanyak 190 data. Pengujian instrumen dengan, uji sub-struktur I, II, dan III kemudian dianalisis dengan Path Analysis. Hasil uji hipotesis penelitian ini menunjukkan bahwa kontribusi pengaruh persepsi anggota pada sharia compliance, komitemen agama dan atribut produk Islam masing-masing berpengaruh secara signifikan dan terhadap keputusan menggunakan jasa lembaga keuangan syariah

Keywords: Persepsi Sharia Compliance, Komitmen Agama, Atribut Produk Islam, Customre's Trust, Keputusan, Path Analysis.

Saran sitasi: Prastiwi, I. (2018). Pengaruh Persepsi Anggota Pada Sharia Compliance, Komitmen Agama Dan Atribut Produk Islam Terhadap Customer's Trust Yang Berdampak Pada Keputusan Menggunakan Jasa Lembaga Keuangan Syariah (Studi Pada BMT Amanah Ummah Sukoharjo).Jurnal Ilmiah Ekonomi Islam, 4(01), 28-40. doi: http://dx.doi.org/10.29040/jiei.v4i1.162

DOI: http://dx.doi.org/10.29040/jiei.v4i1.162

\section{Pendahuluan}

Dunia perbankan syariah yang semakin ramai. Pertumbuhan perbankan syariah semakin berkembang pesat, menandakan penduduk Indonesia yang mayoritas muslim, masyarakatnya semakin tertarik terhadap layanan perbankan yang halal dan sesuai syariah. Menurut Rahmawaty (2014) dalam penelitiannya bahwa persepsi tentang dilarangnya bunga bank dan diperbolehkannya bagi hasil dalam Islam mem- pengaruhi masyarakat di Semarang dalam menggunakan jasa bank syariah. Penelitian Rahmawaty ini menunjukkan bahwa pengetahuan dan pemahaman masyarakat terhadap sistem keuangan berbasis syariah berpengaruh termahap minat menggunakan jasa keuangan Syariah.

Minat masyarakat menggunakam jasa keuangan syariah terus meningkat. Namun jika dilihat secara minat masyarakat Indonesia secara keseluruhan, pemahaman masyarakat terhadap 
layanan dan produk keuangan syariah masih rendah. Hal ini berdasarkan hasil Survei Nasional Literasi dan Inklusi Keuangan (SNLKI) bahwa tahun 2016 hasilnya, indeks literasi keuangan syariah sebesar $8,11 \%$, sedangkan indeks inklusi keuangan syariah 11,06\% (Septyaningsih, 2017).

Masyarakat Indonesia memang sudah banyak yang tahu tentang lembaga keuangan yang berbasis syariah, namun mereka belum tentu tahu tentang produk-produk yang ditawarkannya. Masyarakat yang belum tahu produkproduk yang ditawarkan tentang lembaga keuangan syariah akan menganggap produkproduknya masih kalah dengan produk-produk bank konvensional. Pemahaman dan pengetahuan masyarakat tentang lembaga keuangan syariah akan mempengaruhi pandangannya terhadap lembaga keuangan syariah. Hal ini menyebabkan kurangnya minat masyarakat dalam menggunakan jasa lembaga keuangan syariah.

Baitul Maal wat Tamwil atau BMT sebagai salah satu lembaga keuangan syariah yang semakin berkembang dilingkungan masyarakat. Salah satu BMT terbesar di kabupaten Sukoharjo adalah BMT Amanah Ummah. Jumlah aset BMT Amanah Ummah selalu mengalami peningkatan dari tahun ke tahun selama beberapa tahun terakhir. Perkembangan jumlah aset ini diikuti oleh perkembangan jumlah anggota BMT Amanah Ummah.

Menurut Bapak Faishal Abdul Haris, selaku manajer BMT Amanah Ummah, kendala yang dialami BMT Amanah Ummah adalah kepercayaan masyarakat Sukoharjo terhadap BMT masih perlu ditingkatkan. Anggota masih memilih menyimpan sebagian besar dananya di bank konvensional sedangkan sebagian kecil pada BMT. Menurut Bapak Faishal hal ini karena masyarakat kurang percaya akan keamanan dananya jika dalam jumlah besar, dan komitmen agama dalam menghindari riba masih kurang.

Oleh karena itu, peneliti tertarik untuk melakukan penelitian tentang "Pengaruh persepsi anggota pada Sharia Compliance, komitmen agama dan atribut produk Islam terhadap cus- tomer's trust yang berdampak pada keputusan menggunakan jasa lembaga keuangan syariah (studi pada BMT Amanah Ummah Sukoharjo)". Harapannya penelitian ini mampu membuktikan secara empiris faktor-faktor apa saja yang mempengaruhi masyarakat dalam menggunakan jasa lembaga keuangan syariah.

\section{Tinjauan Pustaka}

\subsection{Persepsi Anggota pada Sharia Compliance}

Persepsi adalah proses bagaimana seseorang menyeleksi, mengatur, dan mengintepretasikan masukan-masukan informasi untuk menciptakan gambaran keseluruhan yang berarti (Kotler dan Keller, 2012). Bila seorang memandang pada suatu objek dan mencoba menafsirkan apa yang dilihatnya, penafsiran itu sangat dipengaruhi oleh karakteristik pribadi dari pelaku persepsi individu itu. Diantara karakterisik pribadi yang mempengaruhi persepsi adalah sikap, kepentingan (minat), motif, pengalaman masa lalu, dan pengharapan (ekspektasi).

Menurut standar AAOIFI (2003) pemenuhan prinsip-prinsip syariah compliance menjadi salah satu pilar penting dalam pengembangan lembaga keuangan syariah. Menurut Antonio (2007) prinsip-prinsip syariah compliance dalam lembaga keuangan syariah/ BMT meliputi:

a. Non Riba

b. Riba (رَبَا) secara bahasa bermakna ziyadah (tambahan). Sebagaimana larangan riba salah satunya Al Quran Surah Al Baqarah (2) ayat 275 yaitu: "Orang-orang yang makan (mengambil) riba tidak dapat berdiri melainkan seperti berdirinya orang yang kemasukan syaitan lantaran (tekanan) penyakit gila..."

c. Zakat

d. Menjauhi Haram

e. Menjauhi Gharar dan Maysir

f. Takaful

Dalam penelitian (Wahyuningsih, 2016) kepatuhan syariah berdasarkan prinsip-prinsip ekonomi Islam indikatornya adalah:

a. Asas saling menguntungkan (tabadu al manafi')

b. Bebas manipulasi ('adam al-gharar) 
c. Halal dan tayyib

d. Tidak mengandung mudharat ('adam al-mudharat)

Berdasarkan uraian diatas, persepsi anggota pada sharia compliance pada BMT Amanah Ummah penulis menggunakan indikator :

a. Bebas Riba

b. Menjalankan baitul maal yaitu menjadi pengelola kegiatan zakat, infak dan sedekah

c. Menjauhi haram

d. Menjauhi maysir dan gharar

e. Asas saling menguntungkan (tabadu al manafi')

f. Halal dan tayyib

g. Tidak mengandung mudharat ('adam al-mudharat)

h. Mengacu kepada fatwa-fatwa syariah DSNMUI.

\subsection{Komitmen Agama}

Menurut El Junusi (2009) komitmen agama adalah suatu bentuk kepatuhan pada ajaran agama. Islam mengatur segala aspek kehidupan sebagaimana firman Allah swt dalam Q.S AlBaqarah ayat 208 "Hai orang-orang beriman, masuklah kamu ke dalam Islam secara keseluruhan ..." Dimensi untuk mengukur komitmen agama adalah: (1) kunjungan ketempat ibadah, (2) partisipasi dalam kegiatan keagamaan dan (3) tingkat kepercayaan agama pribadi.

\subsection{Atribut Produk Islam}

Menurut Iqbal tahun 1997 atribut produk islam adalah atribut produk khas yang ada pada bank syariah, berupa fitur produk yang sesuai dengan sistem keuangan Syariah (El Junusi, 2009). Indikatornya meliputi:

a. Pengharaman bunga

b. Pembagian resiko

c. Uang sebagai modal potensial

d. Larangan perilaku spekulatif

e. Kehalalan kontrak

f. Kegiatan sesuai syariah

Sedangkan menurut Tjiptono (2008: 54) menjelaskan atribut produk Islam adalah beberapa hal yang melekat pada suatu produk perbankan syariah. Indikatornya meliputi:

a. Menghindari unsur riba; b. Hasil investasi dibagi menurut bagi hasil;

c. Menghindari unsur ketidak pastian (gharar);

d. Menghindari unsur gambling/judi (maisir);

e. Melakukan investasi yang halal;

Indikator atribut produk Islam menurut Tjiptono (2008) semuanya sama dengan yang dikemukakan oleh Iqbal tahun 1997, namun indikator atribut produk Islam yang dikemukakan oleh Iqbal memiliki cakupan yang lebih luas (El Junusi, 2009).

Dalam penelitian ini peneliti berpedoman pada indikator atribut produk Islam yang dikemukakan oleh Iqbal (El Junusi, 2009) sebagai berikut:

a. Pengharaman bunga (riba);

b. Pembagian resiko (menggunakan sistem bagi hasil);

c. Uang sebagai modal potensial;

d. Larangan perilaku spekulatif (tidak ada gharar dan maysir);

e. Kehalalan kontrak;

f. Kegiatan sesuai syariah.

\subsection{Kepercayaan Nasabah (Customer's Trust)}

Kepercayaan konsumen (customer trust) adalah keyakinan nasabah bahwa lembaga keuangan syariah akan memberikan sesuai apa yang dijanjikan lembaga tersebut sesuai harapannya. Kepercayaan pada sektor jasa keuangan syariah menjadi sangat penting. Kepercayaan konsumen (customer trust) sebagai katalis dalam transaksi lembaga keuangan syariah dengan nasabah sebagai konsumen agar kepuasan nasabah tercapai sesuai yang diharapkan.

Menurut Cummings dan Bromiley; Mc Allister mengidentifikasi tiga karakteristik kepercayaan, yaitu kognitif, afektif dan perilaku (Ashraf, Robson dan Sekhon, 2015). Menurut Khairani (2015) customer's trust memiliki indikator: (1) kredibilitas; (2) keandalan; (3) kepedulian; (4) keamananan; (5) kerahasiaan; (6) kompensasi kerugian; (7) citra; (8) kejujuran. Dalam penelitian ini peneliti mengambil indikator: (1) kredibilitas; (2) keandalan; (3) kepedulian; (4) keamananan; (5) kerahasiaan; (6) citra; (7) kejujuran. 


\subsection{Pengambilan Keputusan (Decision Making)}

Pengambilan keputusan merupakan proses identifikasi dan pemilihan dari kemungkinan pemecahan masalah sesuai dengan tuntutan situasi (Ahmad, 2012) atau mengidentifikasi dan memilih dari alternatif, pilihan terbaik yang sesuai dengan suatu tujuan (Temitayo dan Omotunde, 2012).

Sedangkan menurut Khairani (2015) indikator pengambilan keputusan adalah:

a. Prioritas pembelian pada produk tertentu;

b. Mencari informasi;

c. Mengevaluasi terhadap produk;

d. Merekomendasikan kepada orang lain setelah melakukan pembelian.

Dalam penelitian ini, peneliti mengambil indikator pengambilan keputusan adalah sebagai berikut:

a. Mengenali Kebutuhan, berlanjut pada prioritas menggunakan pada produk tertentu;

b. Mencari Informasi;

c. Mengevaluasi alternatif lain;

d. Keputusan Membeli;

e. Evaluasi Pasca Pengambilan Keputusan.

Berdasarkan tinjauan pustkaa, maka hipotesis dalam penelitian ini yaiut: 1) Diduga ada pengaruh positif dan signifikan persepsi anggota pada sharia compliance terhadap keputusan menggunakan jasa lembaga keuangan syariah melalui customer's trust (studi pada BMT Amanah Ummah Sukoharjo); 2) Diduga ada pengaruh positif dan signifikan komitmen agama terhadap keputusan menggunakan jasa lembaga keuangan syariah melalui customer's trust (studi pada BMT Amanah Ummah Sukoharjo); 3) Diduga ada pengaruh positif dan signifikan atribut produk Islam terhadap keputusan menggunakan jasa lembaga keuangan syariah melalui customer's trust (studi pada BMT Amanah Ummah Sukoharjo); 4) Diduga ada pengaruh positif dan signifikan persepsi anggota pada sharia compliance, komitmen agama, dan atribut produk Islam terhadap keputusan menggunakan jasa lembaga keuangan syariah baik secara parsial maupun secara simultan (studi pada BMT Amanah Ummah Sukoharjo).

\section{Metode Penelitian}

Jenis penelitian merupakan penelitian kuantitatif, dengan metode survei yang memfokuskan pada hubungan sebab akibat antar variabel. Variabel sebab akibat tersebut adalah persepsi anggota pada sharia compliance $\left(\mathrm{X}_{1}\right)$, komitmen agama $\left(\mathrm{X}_{2}\right)$, atribut produk Islam $\left(\mathrm{X}_{3}\right)$, customer's trust (Y), dan keputusan menggunakan jasa lembaga keuangan syariah $(\mathrm{Z})$

Penelitian ini dilaksanakan mulai Agustus 2017 sampai Februari 2018. Populasi dalam penelitian ini adalah semua anggota BMT Amanah Ummah Sukoharjo. Sampel dalam penelitian ini adalah 190 anggota BMT Amanah Ummah Sukoharjo. Teknik pengambilan sampel dalam penelitian ini adalah metode convenience sampling (sampling kemudahan). Convenience Sampling berarti unit sampling yang ditarik mudah dihubungi dan tidak menyusahkan, mudah untuk mengukur dan bersifat kooperatif (Hamid, 2007).

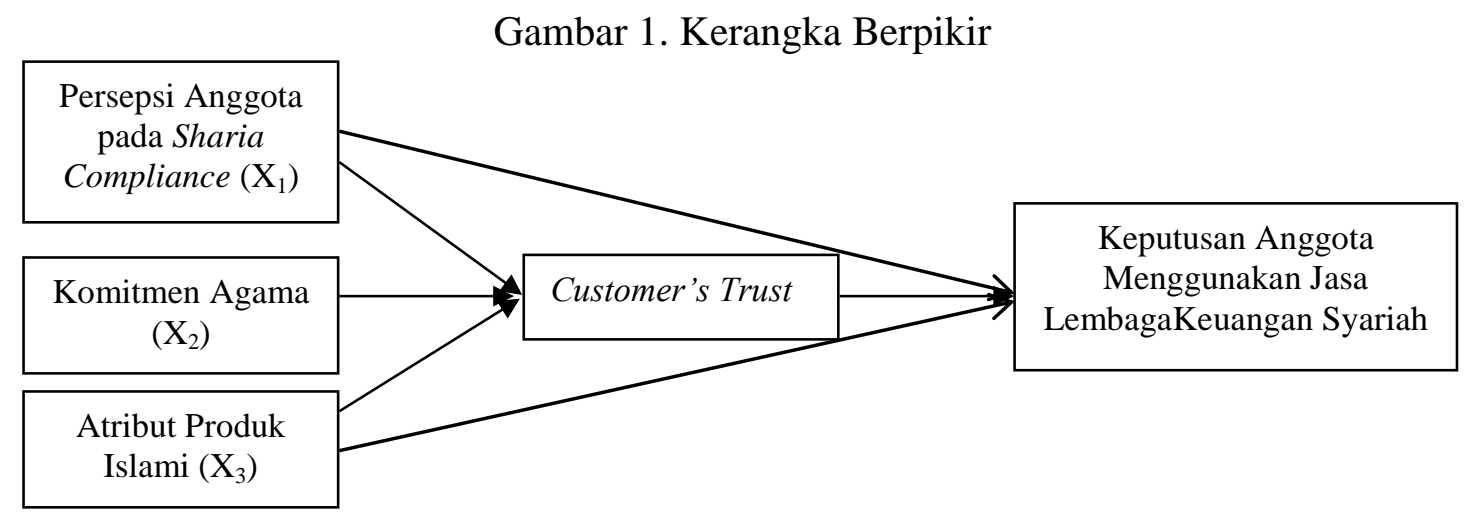


Jurnal Ilmiah Ekonomi Islam, 4(01), 2018, 32

Metode analisis data yang digunakan untuk menguji hipotesis adalah menggunakan path analisis. Teknik analisa ini meliputi dua cara, yaitu sebagai berikut:

\subsection{Metode of Succesive Interval (MSI)}

Salah satu syarat path analysis ini digunakan adalah data berskala interval dan rasio. Dalam penelitian ini data masih berskala ordinal, sehingga perlu mentransformasikan data ordinal menjadi data interval sehingga regresi bisa dilakukan (Riduwan dan Kuncoro, 2013). Teknik transformasi yang paling sederhana adalah Method of Succesive Interval (MSI).

\subsection{Uji Hipotesis}

Untuk pengujian hipotesis, menggunakan analisis jalur (path analysis). Langkah-langkah menguji path analysis dengan cara Merumuskan persamaan structural. Dalam penelitian ini, peneliti merumuskan menjadi 3 persamaan struktural, yaitu sub-struktur I, II, dan III.

Model persamaan dengan analisis jalur sebagai berikut:

Gambar 2. Diagram Jalur Lengkap

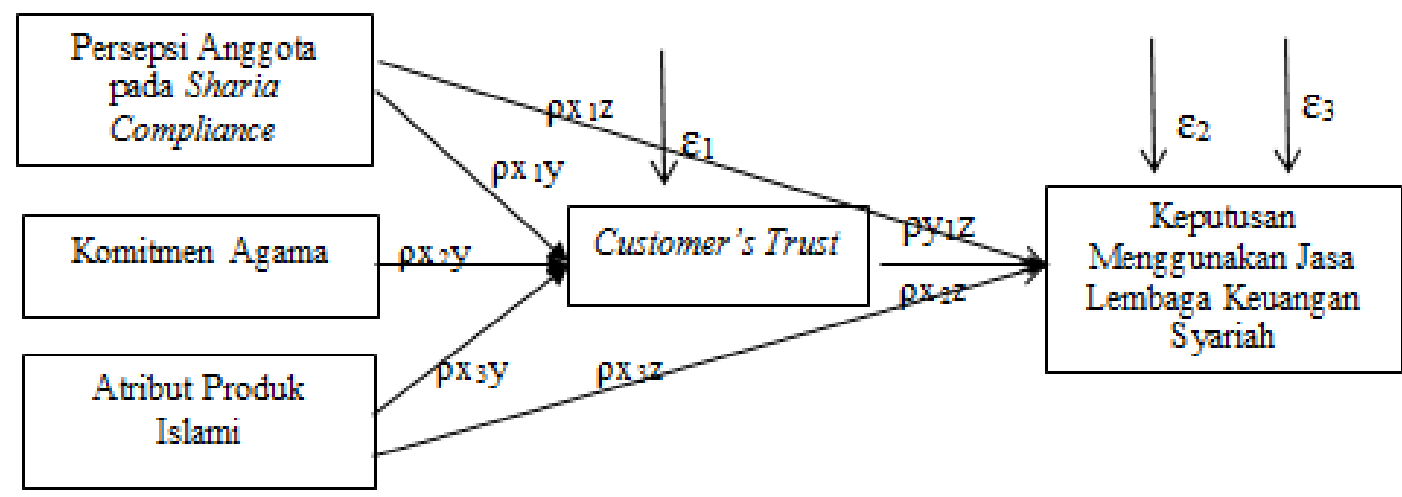

Gambar 3. Hubungan Sub-Struktur I, Variabel $\mathrm{X}_{1}, \mathrm{X}_{2}$ dan $\mathrm{X}_{3}$ Terhadap Y

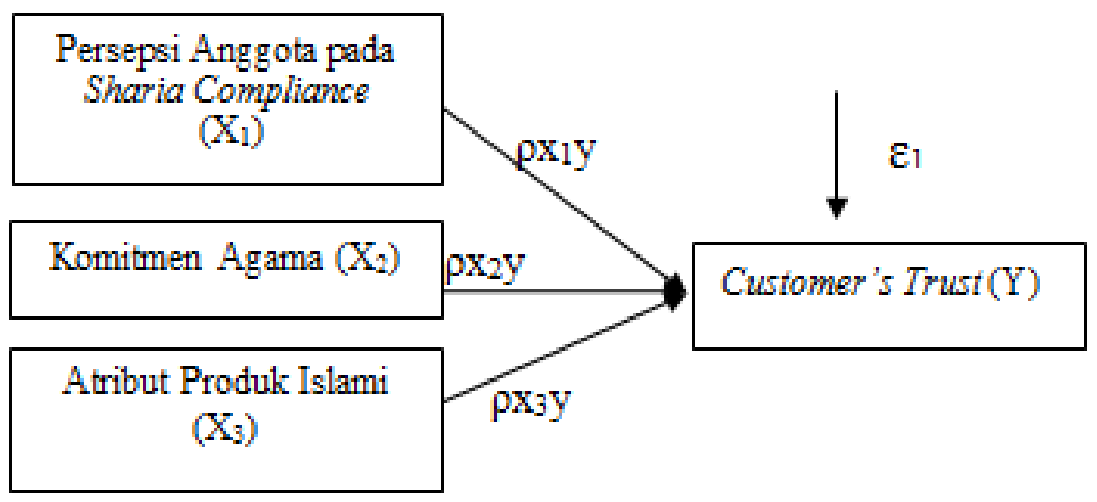

Sub-Struktur 1

$$
\begin{aligned}
& Y=\rho y x_{1} X_{1}+\rho y x_{2} X_{2}+\rho y x_{3} X_{3} \rho y \varepsilon_{1} \\
& Y=\rho y x_{1} X_{1}+\rho y \varepsilon_{1} \\
& Y=\rho y x_{2} X_{2}+\rho y \varepsilon_{1} \\
& Y=\rho y x_{3} X_{3}+\rho y \varepsilon_{1}
\end{aligned}
$$

\begin{tabular}{|c|c|c|}
\hline Customer's Trust $(\mathrm{Y})$ & $\rho z y$ & $\begin{array}{l}\text { Keputusan Menggunakan Jasa } \\
\text { Lembaga Keuangan Syariah }(Z)\end{array}$ \\
\hline
\end{tabular}

Gambar 4. Hubungan Sub-Struktur II, variabel Y terhadap Z

$$
\downarrow \varepsilon_{2}
$$


Sub-Struktur II

$Z=\rho z y Y+\rho z \varepsilon_{2}$

Gambar 5. Hubungan Sub-Struktur III, Variabel $X_{1}, X_{\text {, dan }} X_{3}$ terhadap Z

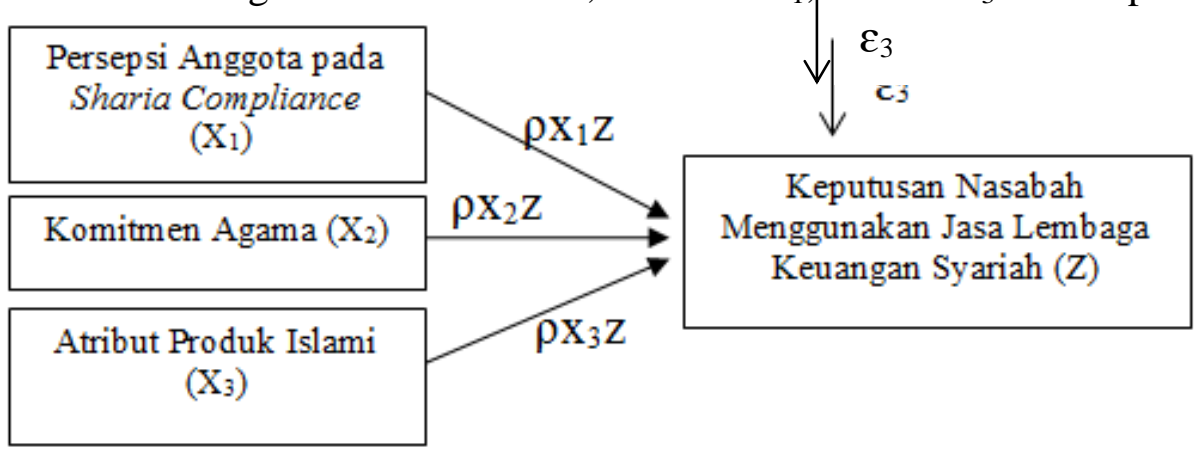

Sub-Struktur III

$$
\begin{aligned}
& Z=\rho z X_{1} X_{1}+\rho z X_{2} X_{2}+\rho z X_{3} X_{3}+\rho z \varepsilon_{3} \\
& Z=\rho z X_{1} X_{1}+\rho z \varepsilon_{3} \\
& Z=\rho z X_{2} X_{2}+\rho z \varepsilon_{3} \\
& Z=\rho z X_{3} X_{3}+\rho z \varepsilon_{3}
\end{aligned}
$$

Dimana :

$\mathrm{X}_{1}=$ Persepsi Anggota pada Sharia Compliance

$\mathrm{X}_{2}=$ Komitmen Agama

$\mathrm{X}_{3}=$ Atribut Produk Islam

$\mathrm{Y}=$ Customer's Trust

$\mathrm{Z}=$ Pengambilan Keputusan Menggunakan Jasa Keuangan Syariah

$$
\varepsilon=\text { error }
$$

\section{Hasil dan Pembahasan}

Kajian ini mengambil responden anggota BMT Amanah Ummah di kabupaten Sukoharjo. Penyebaran kuesioner pada bulan Januari 2018. Data jumlah penyebaran kuesioner pada BMT Amanah Ummah sebagai Tabel 1.

\begin{tabular}{|c|c|c|c|c|}
\hline Pengaruh antar variabel & Koefisien Jalur & $\mathrm{t}$ hitung & t tabel & Hasil Pengujian \\
\hline $\mathrm{X}_{1}$ terhadap $\mathrm{Y}$ & 0,208 & 3,818 & 1,97 & Ho ditolak \\
\hline $\mathrm{X}_{2}$ terhadap $\mathrm{Y}$ & 0,103 & 1,889 & 1,97 & Ho diterima \\
\hline $\mathrm{X}_{3}$ terhadap $\mathrm{Y}$ & 0,587 & 10,684 & 1,97 & Ho ditolak \\
\hline F hitung & 55,956 & F table & 2,65 & Ho ditolak \\
\hline $\mathrm{R}^{2}$ & \multicolumn{2}{|c|}{0,474 atau $47,4 \%$} & & \\
\hline $\begin{array}{l}\text { Koefisien variabel lain } \\
\text { (sisa) } \rho y \varepsilon 1\end{array}$ & \multicolumn{2}{|c|}{0,526 atau $52,6 \%$} & & \\
\hline
\end{tabular}

Tabel 1. Data Sampel Penelitian

\begin{tabular}{clcc}
\hline No & \multicolumn{1}{c}{ Keterangan } & \\
\hline 1 & Jumlah Kuesioner yang disebar & 300 & $100 \%$ \\
2 & Jumlah Kuesioner yang tidak kembali & 110 & $36,67 \%$ \\
3 & Jumlah Kuesioner yang tidak dapat diolah & 0 & $0 \%$ \\
4 & Jumlah Kuesioner yang dapat diolah & 190 & $63,33 \%$ \\
\hline
\end{tabular}

Sumber: Data Primer, 2018

Tabel 2. Rangkuman Hasil Koefisien Jalur Sub Struktur I

Sumber: Data primer, diolah 2018 


\subsection{Hasil Uji Sub Struktur I}

Hasil pengolahan tampak bahwa tabel anova, model summary, dan coefficiens ditunjukkan oleh standardized coefficients (Beta), sedang unstandardized coefficients merupakan koefisien regresi biasa (Riduwan dan Kuncoro, 2013). Pada Tabel 3 menjelaskan coefficients uji Sub Struktur I.

Pada Tabel 3 menunjukkan t hitung persepsi anggota pada sharia compliance sebesar 3,818, sedangkan $\mathrm{t}$ tabel untuk signifikansi $\alpha=0,05$ sebesar 1,97. Apabila t hitung $>\mathrm{t}$ tabel, maka semua variabel independen yang digunakan signifikan berpengaruh terhadap variabel dependen. Berdasarkan Tabel 2 variabel persepsi anggota pada sharia compliance mempunyai $\mathrm{t}$ hitung > t tabel atau 3,818>1,97 maka Ho ditolak, dan Ha diterima, artinya koefisien analisis jalur signifikan berpengaruh. Jadi persepsi anggota pada sharia compliance berpengaruh signifikan terhadap customer's trust. Besarnya pengaruh persepsi anggota pada sharia compliance terhadap customer's trust sebesar $0,208^{2}=0,0433$ atau $4,33 \%$ dengan arah positif.

Sementara t hitung komitmen agama sebesar 1,889, dan t tabel sebesar 1,97. Berdasarkan tabel 2 variabel komitmen agama mempunyai t hitung $<\mathrm{t}$ tabel atau 1,889 < 1,97 maka Ho diterima, dan Ha ditolak, artinya koefisien analisis jalur adalah tidak signifikan berpengaruh. Jadi komitmen agama tidak berpengaruh secara signifikan terhadap customer's trust. Namun, komitmen agama tetap mempunyai kontribusi pengaruh terhadap customer's trust. Besarnya kontribusi pengaruh variabel komitmen agama terhadap customer's trust sebesar $0,103^{2}=$ 0,0106 atau 1,06\% dengan arah positif.

Variabel atribut produk Islam $\mathrm{t}$ hitung sebesar 10,684, t tabel sebesar 1,97. Berdasarkan Tabel 2 variabel atribut produk Islam mempunyai t hitung > t tabel atau 10,684 > 1,97 maka Ho ditolak, dan Ha diterima, artinya koefisien analisis jalur adalah signifikan berpengaruh. Jadi atribut produk Islam berpengaruh secara signifikan terhadap customer's trust. Besarnya kontribusi pengaruh variabel atribut produk Islam terhadap customer's trust sebesar $0,587^{2}=$ 0,3446 atau $34,36 \%$ dengan arah positif.

Terlihat pada tabel 3 menunjukkan $\mathrm{F}$ hitung sebesar 55,956, sedangkan $\mathrm{F}$ tabel untuk signifikansi $\alpha=0,05$ sebesar 2,65. Apabila $F$ hitung $>$ $F$ tabel, maka semua variabel independen secara bersama-sama signifikan berpengaruh terhadap variabel dependen. Berdasarkan Tabel 2, F hitung > F tabel atau 55,956 > 2,65 maka keputusannya adalah Ho ditolak dan Ha diterima, artinya koefisien analisis jalur adalah signifikan berpengaruh. Jadi persepsi anggota pada syariah compliance dan komitmen agama dan atribut produk Islam berpengaruh secara bersama-sama dan signifikan terhadap customer's trust, sehingga pengujian dapat dilanjutkan.

Untuk melihat besarnya pengaruh pengaruh persepsi anggota pada syariah compliance dan komitmen agama dan atribut produk Islam secara gabungan dapat dilihat $\mathrm{R}^{2}$ ( $\mathrm{R}$ square) sebesar 0,474 atau $47,4 \%$, artinya persepsi anggota pada syariah compliance, komitmen agama dan atribut produk Islam secara bersama-sama mempengaruhi customer's trust sebesar 47,4\%. Adapun sisanya sebesar $52,6 \%$ dipengaruhi oleh variabel lain yang tidak disebutkan dalam model.

\subsection{Hasil Uji Sub Struktur II}

Terlihat pada tabel 4 menunjukkan $\mathrm{t}$ hitung customer's trust sebesar 11,177, sedangkan t tabel untuk signifikansi $\alpha=0,05$ sebesar 1,653. Apabila $\mathrm{t}$ hitung $>\mathrm{t}$ tabel, maka semua variabel independen yang digunakan signifikan berpengaruh terhadap variabel dependen. Berdasarkan Tabel 3 variabel customer's trust mempunyai $\mathrm{t}$ hitung $>\mathrm{t}$ tabel atau 11,177 > 1,653 maka Ha ditolak dan Ho diterima, artinya koefisien analisis jalur berpengaruh signifikan. Jadi customer's trust berpengaruh secara positif dan signifikan terhadap keputusan menggunakan jasa keuangan syariah sebesar $0,632^{2}=0,3994$ atau 39,94\%.

Terlihat pada tabel 4 menunjukkan $\mathrm{F}$ hitung sebesar 124,925, sedangkan F tabel untuk signifikansi $\alpha=0,05$ sebesar 3,89. Apabila $F$ hitung $>$ 
F tabel, maka keputusannya adalah Ho ditolak dan Ha diterima, artinya koefisien analisis jalur adalah signifikan. Berdasarkan Tabel 3, F hitung $>$ F tabel atau 124,925 > 3,89. Jadi customer's trust berpengaruh signifikan terhadap keputusan menggunakan jasa keuangan syariah, sehingga penelitian bisa dilanjutkan.

Untuk melihat pengaruh customer's trust terhadap keputusan menggunakan jasa keuangan syariah dapat dilihat $\mathrm{R}^{2}$ ( $\mathrm{R}$ square) sebesar 0,399 atau $39,9 \%$, artinya customer's trust mempengaruhi menggunakan jasa keuangan syariah sebesar $39,9 \%$. Adapun sisanya sebesar $60,1 \%$ dipengaruhi oleh variabel lain yang tidak disebutkan dalam model.

\subsection{Hasil Uji Sub Struktur III}

Terlihat pada Tabel 4 menunjukkan $\mathrm{t}$ hitung persepsi anggota pada sharia compliance sebesar 3,008, sedangkan $\mathrm{t}$ tabel untuk signifikansi $\alpha=0,05$ dan $\mathrm{df}=\mathrm{n}-\mathrm{k}$ atau $\mathrm{df}=190-4=186$ maka diperoleh $t$ tabel sebesar 1,286. Apabila t hitung $>\mathrm{t}$ tabel, maka semua variabel independen yang digunakan signifikan berpengaruh terhadap variabel dependen. Berdasarkan Tabel 5, variabel persepsi anggota pada sharia compliance mempunyai $\mathrm{t}$ hitung $>\mathrm{t}$ tabel atau 3,008 $>1,286$ maka Ha diterima, dan Ho ditolak, artinya koefisien analisis jalur berpengaruh signifikan. Persepsi anggota pada sharia compliance berpengaruh secara positif dan signifikan terhadap keputusan menggunakan jasa keuangan syariah sebesar $0,194^{2}=0,0376$ atau $3,76 \%$.

Variabel komitmen agama menunjukkan $\mathrm{t}$ hitung sebesar 2,670, dan t tabel sebesar 1,286.
Berdasarkan Tabel 4, variabel komitmen agama mempunyai $\mathrm{t}$ hitung $>\mathrm{t}$ tabel atau 2,670>1,286 maka Ho ditolak, dan Ha diterima, artinya koefisien analisis jalur adalah signifikan. Jadi komitmen agama berpengaruh signifikan terhadap keputusan menggunakan jasa keuangan syariah sebesar $0,171^{2}=0,0292$ atau $2,92 \%$ dengan arah negatif.

Variabel atribut produk Islam menunjukkan, t hitung sebesar 6,876, dan t tabel sebesar 1,286. Berdasarkan Tabel 5, variabel atribut produk Islam mempunyai t hitung > t tabel atau 6,876 > 1,286 maka Ho ditolak, dan Ha diterima, artinya koefisien analisis jalur adalah signifikan. Jadi atribut produk Islam berpengaruh secara positif signifikan terhadap keputusan menggunakan jasa keuangan syariah sebesar $0,447^{2}=0,1998$ atau $19,98 \%$.

Terlihat pada tabel 5 menunjukkan $\mathrm{F}$ hitung sebesar 22,370, sedangkan $F$ tabel untuk signifikansi $\alpha=0,05$ dan $\mathrm{df} 1=3$ atau $\mathrm{df}=186$ maka diperoleh $F$ tabel sebesar 2,65. Apabila $F$ hitung > F tabel, maka semua variabel independen secara bersama-sama signifikan berpengaruh terhadap variabel dependen. Berdasarkan Tabel $4 \mathrm{~F}$ hitung > F tabel atau 22,370 > 2,65 maka keputusannya adalah Ho ditolak dan $\mathrm{Ha}$ diterima, artinya koefisien analisis jalur adalah signifikan. Jadi persepsi anggota pada sharia compliance, komitmen agama, dan atribut produk Islam berpengaruh secara bersama-sama dan signifikan terhadap keputusan menggunakan jasa lembaga keuangan syaria

Tabel 3. Tangkuman Hasil Koefisien Jalur Sub Struktur II

\begin{tabular}{llccc}
\hline \multicolumn{1}{c}{$\begin{array}{c}\text { Pengaruh antar } \\
\text { variabel }\end{array}$} & $\begin{array}{c}\text { Koefisien Jalur } \\
\text { Beta }\end{array}$ & t hitung & t tabel & $\begin{array}{c}\text { Hasil Pengujian } \\
\text { Parsial }\end{array}$ \\
\hline Y terhadap Z & \multicolumn{1}{c}{0,632} & 11,177 & 1,653 & Ho ditolak \\
\hline F hitung & 124,925 & & & \\
F tabel & 3,89 & & & \\
Hasil Pengujian & Ho Ditolak & & & \\
Simultan & 0,399 atau 39,9\% & & & \\
$\mathrm{R}^{2}$ & & & \\
Koefisien variabel & 0,601 atau 60,1\% & & & \\
lain (sisa) $\rho z \varepsilon_{2}$ & & & & \\
\hline
\end{tabular}

Sumber: Data primer, diolah 2018 
Jurnal Ilmiah Ekonomi Islam, 4(01), 2018, 36

Tabel 4. Tangkuman Hasil Koefisien Jalur Sub Struktur III

\begin{tabular}{lcccc}
\hline \multicolumn{1}{c}{$\begin{array}{c}\text { Pengaruh antar } \\
\text { variabel }\end{array}$} & $\begin{array}{c}\text { Koefisien Jalur } \\
\text { Beta }\end{array}$ & t hitung & t tabel & $\begin{array}{c}\text { Hasil Pengujian } \\
\text { parsial }\end{array}$ \\
\hline \multicolumn{1}{c}{$\mathrm{X}_{1}$ terhadap Z } & 0,194 & 3,008 & 1,286 & Ho ditolak \\
$\mathrm{X}_{2}$ terhadap Z & $-0,171$ & $-2,670$ & 1,286 & Ho ditolak \\
\multicolumn{1}{c}{$\mathrm{X}_{3}$ terhadap Z } & 0,447 & 6,876 & 1,286 & Ho ditolak \\
\hline F hitung & 22,370 & & \\
F tabel & 2,65 & & & \\
Hasil Pengujian & Ho Ditolak & & \\
Simultan & 0,265 atau 26,5\% & & \\
$\mathrm{R}^{2}$ & & & \\
Koefisien variabel lain & 0,735 atau 73,5\% & & \\
(sisa) $\rho z \varepsilon_{3}$ & & & \\
\hline
\end{tabular}

Sumber: Data primer, diolah 2018

Tabel 5. Koefisien jalur, kontribusi langsung, tidak langsung, kontribusi total

\begin{tabular}{|c|c|c|c|c|}
\hline \multirow[b]{2}{*}{ Variabel } & \multicolumn{4}{|c|}{ Kontribusi } \\
\hline & Langsung & Tidak Langsung (melalui Y) & $\begin{array}{c}\text { Sisa } \varepsilon_{1,} \varepsilon_{2} \\
\text { dan } \varepsilon_{3}\end{array}$ & Total \\
\hline $\mathrm{X}_{1}$ & 0,194 & $0,194+(0,208 \times 0,632)=0,3255$ & & 0,3255 \\
\hline $\mathrm{X}_{2}$ & $-0,171$ & $-0,171(0,103 \times 0,632)=-0,1059$ & & $-0,1059$ \\
\hline$X_{3}$ & 0,447 & $0,447(0,587 \times 0,632)=0,828$ & & 0,828 \\
\hline $\mathrm{X}_{1}, \mathrm{X}_{2} \mathrm{X}_{3} \rightarrow \mathrm{Y}$ & 0,474 & & 0,526 & \\
\hline $\mathrm{Y} \rightarrow \mathrm{Z}$ & 0,399 & & 0,601 & \\
\hline $\mathrm{X}_{1}, \mathrm{X}_{2} \mathrm{X}_{3} \rightarrow \mathrm{Z}$ & 0,265 & & 0,735 & \\
\hline
\end{tabular}

Sumber: Data primer, diolah 2018

Untuk melihat besarnya pengaruh persepsi anggota pada sharia compliance, komitmen agama, dan atribut produk Islam berpengaruh secara bersama-sama dan signifikan terhadap keputusan menggunakan jasa keuangan syariah secara gabungan dapat dilihat $\mathrm{R}^{2}$ ( $\mathrm{R}$ square) sebesar 0,265 atau $26,5 \%$, artinya persepsi anggota pada sharia compliance, komitmen agama, dan atribut produk Islam secara bersama-sama mempengaruhi keputusan menggunakan jasa keuangan syariah sebesar $26,5 \%$. Adapun sisanya sebesar 73,5\% dipengaruhi oleh variabel lain yang tidak disebutkan dalam model.

Berdasarkan hasil perhitungan analisis jalur tersebut, maka dapat dijelaskan sebagai berikut:

a) Besarnya kontribusi persepsi anggota pada sharia compliance $\left(\mathrm{X}_{1}\right)$ yang secara langsung dan signifikan mempengaruhi keputusan menggunakan jasa lembaga keuangan syariah (Z) adalah 0,194 dengan arah positif, sedang- kan besarnya kontribusi pengaruh tidak langsung persepsi anggota pada sharia compliance $\left(\mathrm{X}_{1}\right)$ terhadap keputusan menggunakan jasa lembaga keuangan syariah (Z) melalui customer's trust (Y) sebesar 0,3255

b) Besarnya kontribusi komitmen agama $\left(\mathrm{X}_{2}\right)$ yang secara langsung dan signifikan mempengaruhi keputusan menggunakan jasa lembaga keuangan syariah ( $\mathrm{Z}$ ) adalah 0,171 dengan arah negatif, sedangkan besarnya kontribusi pengaruh tidak langsung komitmen agama $\left(\mathrm{X}_{2}\right)$ terhadap keputusan menggunakan jasa lembaga keuangan syariah (Z) melalui customer's trust (Y) sebesar 0,1059 dengan arah negatif

c) Besarnya kontribusi atribut produk Islam $\left(\mathrm{X}_{3}\right)$ yang secara langsung dan signifikan mempengaruhi keputusan menggunakan jasa lembaga keuangan syariah (Z) adalah 0,447 dengan arah positif, sedangkan besarnya 
kontribusi pengaruh tidak langsung atribut produk Islam $\left(\mathrm{X}_{3}\right)$ terhadap keputusan menggunakan jasa lembaga keuangan syariah (Z) melalui customer's trust (Y) sebesar 0,828 dengan arah positif.

d) Besarnya kontribusi persepsi anggota pada sharia compliance $\left(\mathrm{X}_{1}\right)$, komitmen agama $\left(\mathrm{X}_{2}\right)$, dan atribut produk Islam $\left(\mathrm{X}_{3}\right)$ secara simultan dan signifikan mempengaruhi keputusan menggunakan jasa lembaga keuangan syariah (Z) adalah 26,5\%. Sisanya sebesar $73,5 \%$ dipengaruhi oleh faktor-faktor lain yang tidak dijelaskan dalam penelitian.

Kontribusi Persepsi anggota pada sharia compliance terhadap keputusan menggunakan jasa lembaga keuangan syariah

Variabel persepsi anggota pada sharia compliance memiliki nilai $\mathrm{t}$ hitung $>\mathrm{t}$ tabel atau $3,008>1,286$ artinya persepsi anggota pada sharia compliance berpengaruh signifikan terhadap keputusan menggunakan jasa lembaga keuangan syariah. Besarnya kontribusi persepsi anggota pada sharia compliance sebesar 0,194 dengan arah positif. Artinya semakin tinggi persepsi calon anggota pada sharia compliance, maka semakin mempengaruhi calon anggota mengambil keputusan menggunakan jasa lembaga keuangan syariah. Sedangkan besarnya kontribusi pengaruh tidak langsung melalui customer's trust sebesar 0,3255.

Hasil penelitian ini dapat dijelaskan bahwa calon anggota menggunakan jasa lembaga keuangan syariah yang diproksikan dengan BMT bukan hanya berdasarkan kebutuhan saja, namun juga yang sesuai syariah. Calon anggota BMT pada umumnya juga mengharapkan BMT bisa menerapkan syariah compliance dengan baik yaitu non riba, menjauhi haram, menjauhi gharar, maisir serta ada program zakatnya. BMT yang menerapkan syariah compliance dengan baik maka calon anggota akan mempunyai kepercayaan (customer's trust) yang tinggi terhadap BMT sehingga berdampak pada calon anggota akan menggunakan jasa BMT, baik dalam menyimpan uangnya maupun mengajukan pembiayaan.

Hasil penelitian ini sesuai dengan penelitian sebelumnya yang dilakukan oleh Sofiyah (2015) bahwa label syariah merupakan faktor yang mempengaruhi keputusan nasabah menggunakan jasa Bank Syariah Mandiri. Namun, hasil penelitian ini berbeda dengan penelitian Atmoko (2016) bahwa persepsi anggota pada sharia compliance tidak berpengaruh terhadap keputusan menggunakan jasa pembiayaan pada BMT Binamas Cabang Kutoarjo.

\section{Kontribusi komitmen agama terhadap kepu- tusan menggunakan jasa lembaga keuangan syariah}

Variabel komitmen agama memiliki t hitung $<\mathrm{t}$ tabel yaitu 2,670, > 1,286 artinya komitmen agama berpengaruh signifikan terhadap keputusan menggunakan jasa lembaga keuangan syariah. Besarnya kontribusi pengaruh komitmen agama keputusan menggunakan jasa lembaga keuangan syariah sebesar 0,171 dengan arah negatif, Hal ini berarti semakin tinggi komitmen agama calon anggota, maka semakin menurunkan kemungkinan mengambil keputusan menggunakan jasa BMT Amanah Ummah. Sedangkan besarnya kontribusi pengaruh tidak langsung melalui curtomer's trust sebesar 0,1059.

Hasil pengujian ini bisa dijelaskan bahwa semakin kuat komitmen agama dapat menurunkan minat masyarakat mengambil keputusan menggunakan jasa lembaga keuangan syariah. Semakin kuat komitmen agama seseorang akan berpandangan bahwa tidak ada lembaga keuangan syariah yang syariah $100 \%$. Walaupun sedikit pasti ada ribanya. Hal ini dapat menjadikan turunnya kepercayaan seseorang terhadap lembaga keuangan syariah. Persepsi seperti ini menjadikan masyarakat enggan mengambil keputusan menggunakan jasa lembaga keuangan syariah manapun, termasuk BMT.

Penelitian ini tidak sesuai dengan penelitian sebelumnya oleh Ma'arif (2016); Asraf dan Erdawati (2017) bahwa komitmen agama (religi- 
sitas) berpengaruh signifikan terhadap keputusan menggunakan jasa bank syariah

\section{Kontribusi atribut produk Islam terhadap keputusan menggunakan jasa lembaga keu- angan syariah}

Variabel atribut produk Islam memiliki $\mathrm{t}$ hitung > t tabel atau 6,876 > 1,286 artinya atribut produk Islam berpengaruh signifikan terhadap keputusan menggunakan jasa lembaga keuangan syariah. Besarnya kontribusi pengaruh atribut produk Islam sebesar 0,477 dengan arah positif. Hal ini berarti semakin berkualitas atribut produk Islam BMT Amanah Ummah, maka semakin tinggi keputusan menggunakan jasa BMT Amanah Ummah. Sedangkan besarnya kontribusi pengaruh tidak langsung melalui curtomer's trust sebesar 0,828 .

Hasil pengujian atribut produk Islam berpengaruh meningkatkan keputusan menggunakan jasa lembaga keuangan syariah dapat dijelaskan bahwa menurut Tjiptono (2008) atribut produk Islam adalah beberapa hal yang melekat pada suatu produk perbankan syariah. Indikatornya meliputi: (a)menghindari unsur riba; (b)hasil investasi dibagi menurut bagi hasil; (c)menghindari unsur ketidak pastian (gharar); (d)menghindari unsur gambling/judi (maisir); (e) melakukan investasi yang halal.

Semakin produk-produk lembaga keuangan syariah memenuhi indikator atribut produk Islam, semakin baik kualitas atribut produk Islam, semakin tinggi kepercayaan masyarakat (curtomer's trust), baik pula respon masyarakat yang berdampak pada pengambilan keputusan menggunakan jasa lembaga keuangan syariah.

BMT Amanah Ummah harus menjaga kemurnian syariah dalam menawarkan produk simpanan dan pembiayaan. Pengawasan syariah oleh pengawas syariah BMT Amanah Ummah selama ini sudah dilakukan dengan rutin untuk menjaga aktivitas operasional sesuai syariah. BMT Amanah Ummah juga perlu memberikan sosialisasi kepada anggotanya tentang produkproduknya agar tidak terjadi kesalahpahaman dan kekhawatiran karena masih ada yang berpendapat produk-produk simpanan dan pembiayaan BMT Amanah Ummah sama saja dengan bank konvensional

\section{Kesimpulan}

Berdasarkan hasil penelitian dan pembahasan diatas maka dapat disimpulkan: (1) persepsi anggota pada sharia compliance berpengaruh secara signifikan terhadap keputusan menggunakan jasa lembaga keuangan syariah sebesar arah positif; (2) komitmen agama berpengaruh secara signifikan terhadap keputusan menggunakan jasa lembaga keuangan syariah sebesar arah negatif; (3) atribut produk Islam berpengaruh secara signifikan terhadap keputusan menggunakan jasa lembaga keuangan syariah dengan arah positif. Hal ini berarti masyarakat menggunakan jasa BMT Amanah Ummah bukan hanya berdasarkan kebutuhan saja, namun yang sesuai syariah juga. Selain itu BMT Amanah Ummah perlu meningkatkan kualitas produk-produk simpanan dan pembiayaan serta menjaga agar produk-produknya sesuai syariah. Hal ini akan meningkatkan kepercayaan calon anggota, yang berdampak pada keputusan menggunakan jasa lembaga keuangan syariah.

Dari hasil studi empiris penelitian ini, maka beberapa saran bagi penelitian selanjutnya yaitu; 1) Variabel-variabel yang menjadi indikator untuk mengetahui faktor-faktor yang mempengaruhi keputusan masyarakat dalam memilih jasa lembaga keuangan syariah pada penelitian selanjutnya dapat dikembangkan lebih banyak lagi; 2) Perlunya ada upaya dalam meningkatkan pemahaman masyarakat terhadap penerapan sharia compliance dengan sosialisasi dari berbagai pihak baik akademisi maupun praktisi keuangan syariah agar masyarakat menjadi lebih positif dalam memandang penerapan sharia compliance.

\section{Ucapan Terimakasih}

Penulis mengucapkan terima kasih kepada segenap keluarga besar STIE AAS Surakarta atas dukungannya dalam menyelesaikan penelitian ini, serta pimpinan dan karyawan BMT Amanah 
Ummah atas kesediaannya yang telah banyak membantu terlaksananya penelitian ini. Terima kasih juga untuk mahasiswa prodi Ekonomi Islam STIE AAS Surakarta serta semua pihak yang banyak membantu dalam penelitian ini.

\section{Daftar Pustaka}

Al Tarawneh, Hussien Ahmad. (2012). The Main Factors beyond Decision Making. Journal of Management Research. Vol.4 No.1. Bussiness Administration Faculty, Islamic International University

Antonio, Muhammad Syafei. (2007). Bank Syari'ah dan Teori ke Praktek. Jakarta: Gema Insani.

Ashraf, Samren., Robson, Julie.,dan Sekhon, Yasmin (2015). Consumer Trust And Confidence In The Compliance Of Islamic Banks. Journal of Financial Services Marketing, 20(2), 133-144.

Asraf, M. Saleh Lubis dan Erdawati. (2017). Religiusity Moderation On The Effect Of Sharia Label Equity In Decision Of Selecting Sharia Bank Mandiri Product In West Pasaman. Jurnal Penelitian Sosial dan Ekonomi, Vol. 2, No.1. Sekolah Tinggi Ilmu Ekonomi Pasaman Simpang Empat

Atmoko, Widodo Dwi. (2016). Pengaruh Persepsi Anggota pada Sharia Compliance, harga jual dan tingkat margin Terhadap Keputusan Pengambilan Pembiayaan Murabahah di BMT Binamas Cabang Kutoarjo. Skripsi publikasi ilmiah. UIN Sunan Kalijaga Yogyakarta Fakultas Ekonomi dan Bisnis Islam

El Junusi, Rahman. (2009). Pengaruh Atribut Produk Islam, Komitmen Agama, Kualitas Jasa dan Kepercayaan Terhadap Kepuasan Dan Loyalitas Nasabah Bank Muamalat Kota Semarang. Annual Conference on Islamic Studies (ACIS). 2-5 November 2009. Surakarta.

Hamid, Abdul. (2007). Pedoman Penulisan Skripsi. Jakarta: FEIS UIN Syarif Hidayatullah

Khairani, Siti. (2015). Pengaruh Kepercayaan Kualitas Informasi Dan Pelayanan Terhadap Keputusan Membeli Melalui Media Sosial (Studi Kasus Mahasiswa
Akuntansi STIE MDP): Seminar Nasional Manajemen Dan Akuntansi (Snema) Fakultas Ekonomi Universitas Negeri Padang

Kotler, Philip dan Keller, Kevin Lane. (2012). Marketing Management. Edisi ke 14.

Ma'arif, Saiful. (2016). Faktor-faktor yang Mempengaruhi Keputusan Nasabah Bertransaksi di Bank Syariah: Studi Kasus di Bank Mandiri Cabang Boyolali. Skripsi publikasi ilmiah. Surakarta: Universitas Muhammadiyah Surakarta, Fakultas Ekonomi dan Bisnis

Rahmawaty, Anita. (2014). Pengaruh Persepsi Tentang Bank Syariah Terhadap Minat Menggunakan Produk di BNI Syariah Semarang. Jawa Tengah: STAIN Kudus. Jurnal ADDIN, Vol.8, No.1

Riduwan, dan Kuncoro, Engkos Achmad. (2013). Cara Menggunakan dan Memakai Path Analysis (Analisis Jalur). Bandung: Alfabeta. Cetakan kelima.

Septyaningsih, Iit dan Raharjo, Budi. (2017). Survei OJK, Pemahaman Masyarakat Terhadap Keuangan Syariah Masih Rendah. http://www.republika.co.id/berita/ekonomi/s yariah-ekonomi/17/01/24/okae67415-surveiojk-pemahaman-masyarakat-terhadapkeuangan-syariah-masih-rendah diunduh pada tanggal 28 Agustus 2017 jam 13:04

Sofiyah. (2015). Pengaruh persepsi anggota pada syariah compliance dan margin terhadap keputusan pengambilan pembiayaan murabahah (Studi Kasus Di BMT Indoarta Syariah Temanggung, BMT Bima Magelang, dan BMT Anda Salatiga). Skripsi. Salatiga: IAIN Salatiga

Standar AAOIFI (2003) tentang Standar Pemerintahan Lembaga Keuangan Islam No.1 mengenai Dewan Pengawas Syariah

Temitayo Ahmed, Maryam dan Omotunde, Habeeb. (2012). Theories And Strategies of Good Decision Making. International Journal Of Scientific and Technology Research. Vol 1. Issue 10. Malaysia: University of Nottingham Malaysia and Universiti Teknologi Malaysia

Tjiptono, Fandy. (2008). Strategi Pemasaran Edisi 3. Yogyakarta: Andi Offset 
Jurnal Ilmiah Ekonomi Islam, 4(01), 2018, 40

Wahyuningsih, Sri. (2016). Pengaruh Kepercayaan, Keamanan, Syariah Compliance, dan Persepsi akan Risiko Situs jejaring Sosial. Skripsi. Universitas Terhadap Keputusan Pembelian Melalui 